\title{
Age related cranial characters from the viewpoint of species identification of Amur and Daurian hedgehogs (Lipotyphla: Erinaceidae)
}

\begin{abstract}
Leonid L. Voyta
ABSTRACT. The current paper represents a summary of age determination attempts in two species of EastAsian hedgehogs - Erinaceus amurensis Schrenk, 1859, and Mesechinus dauuricus (Sundevall, 1842) from Russian (Moscow, Saint Petersburg) and Chinese (Beijing) Museum Collections. The analysed specimens comprise 99 skulls, of which 46 skulls are from Amur hedgehogs, and 53 belonged to Daurian hedgehogs. Our results represent the four relative age stages with detailed descriptions and figures from the viewpoint of an interspecies comparison. We revealed that the size and additive characters of suprameatal fossa are undoubtedly very useful for the identification of adult specimens of both species, but are useless for young specimens due to the similarity of the initial stages of development of the ear region. In addition, the relative height of the frontal and parietal bones (= development of the sagittal ridge and temporal line) cannot be used to correctly compare subadult and adult Amur hedgehogs with adult and senile Daurian hedgehogs, because the latter species acquires a similarity in the skull profile with the former during maturity. The third considered age-related character is fusion of the lacrimal/maxilla suture, which shows some degree of variation in E. amurensis. Thus, all of the characteristics that are generally used for the comparison and identification of East-Asian hedgehogs, beginning with E. amurensis vs. M. dauuricus, require a prior description of their interspecific variability in order to be useful for species identification. How to cite this article: Voyta L.L. 2017. Age related cranial characters from the viewpoint of species identification of Amur and Daurian hedgehogs (Lipotyphla: Erinaceidae) // Russian J. Theriol. Vol.16. No.2. P.176-184. doi: 10.15298/rusjtheriol.16.2.06
\end{abstract}

KEY WORDS: Erinaceus amurensis, Mesechinus dauuricus, age variability, species identification, Erinaceinae.

Leonid L.Voyta [leonid.voyta@zin.ru], Zoological Institute, Russian Academy of Sciences, Universitetskaya nab. 1, Saint Petersburg 199034, Russia.

\section{Связанные с возрастом краниологические признаки с точки зрения видового определения амурского и даурского ежей (Lipotyphla: Erinaceidae)}

\section{Л.Л. Войта}

РЕЗЮМЕ. В настоящей статье представлены попытки определения возраста двух видов восточноазиатских ежей - Erinaceus amurensis Schrenk, 1859 и Mesechinus dauuricus (Sundevall, 1842), из российских (Москва, Санкт-Петербург) и китайских (Пекин) музейных коллекций. Общее число исследованных экземпляров составляет 99 черепов, из которых - 46 черепов амурского ежа, и 53 черепа принадлежат даурскому ежу. Наши результаты представляют четыре относительные возрастные стадии с их детальными описаниями и рисунками в свете межвидовых сравнений. Мы выявили, что размер и дополнительные признаки надслуховой ямки несомненно очень важны для определения взрослых особей обоих видов, но бесполезны для молодых животных из-за сходства начальных стадий развития слуховой области. Также, относительная высота лобной и теменной костей (= развитие сагиттального гребня и височной линии) не может быть использована для корректного сравнения неполовозрелых и взрослых особей E. amurensis со взрослыми и старыми особями $M$. dauuricus, поскольку последний вид приобретает сходство в профиле черепа с первым видом по мере старения. Третий связанный с возрастом признак, облитерация шва слезной и верхнечелюстной костей, показывает некоторую степень изменчивости для E. amurensis. Таким образом, все признаки, которые предполагаются для сравнений и определения восточно-азиатских ежей, в первую очередь E. amurensis и M. dauuricus, требуют предварительного описания внутривидовой изменчивости.

КЛЮЧЕВЫЕ СЛОВА: Erinaceus amurensis, Mesechinus dauuricus, возрастная изменчивость, видовое определение, Erinaceinae. 


\section{Introduction}

Age related factors affecting the morphological changes in the skull and teeth have important implications for the results of intra- and interspecies analyses based on qualitative or quantitative datasets. Differences in the age structure of compared samples can at least shift average values of measurements, and may even complicate the species definition. In addition, many ethological, demographic, and physiological studies, among others, would be impossible without knowing the age stages of the samples. Conventional methods of mammalian age determination based upon the study of continuous processes such as increases in body dimensions or weight, fusion of epiphyses, increases in dry weight of the eye lens, or teeth wearing processes; or determination based upon periosteal growth lines (Morris, 1970, 1971; Reeve, 1994; Klevesal, 2007), cannot be used for museum specimens. World museum collections contain many hedgehog specimens, which have been collected since the middle of the 19th century (as results of the first Asian scientific explorations by Schrenk, Przhewalsky, Anderson, etc.). Most important specimens - type specimens, as well as other hedgehog collections, are mainly presented as dry units (skulls and skins), and in these cases we can only determine relative age stages.

The current paper represents a summary of age determination attempts in two species of East Asian hedgehogs - Erinaceus amurensis Schrenk, 1859, and Mesechinus dauuricus (Sundevall, 1842) from Russian (Moscow, Saint Petersburg) and Chinese (Beijing) museum collections. The relationship between diagnostic characteristics and age is a special question that we try to solve in this paper.
An introduction to hedgehog diagnostic morphology

The early hedgehog studies of Matschie (1908), Thomas (1908), and Mori (1922) contained rather detailed descriptions of external features (pelage, spines, etc.) and cranial morphology. Later, Corbet (1988) chose and comprehensively described diagnostic features for hedgehogs. According his study (Corbet, 1988: 134-135), twenty-three characters are available for the differentiation of East Asian hedgehogs, of which eight correspond to cranial and dental differences between Amur and Daurian hedgehogs (Table 1). However, Corbet did not consider them directly for the differentiation of these species as they belong to different genera. Building on Corbet's descriptions of characteristics, Zaitsev showed their variation (Zaitsev et al., 2014). For example, the number of roots of the upper canine (Table 1: \#6) may vary: E. amurensis has single-rooted (72.5\%), or double-rooted (27.5\%) teeth; in M. dauuricus, about $15 \%$ of individuals have single-rooted teeth (roots are completely fused), the rest having doublerooted canines $(85 \%)$ ). The upper third incisor I3 (Table 1: \#5) of $M$. dauuricus is two-rooted $(90 \%)$, but partly fused roots were recorded too (10\%) (Zaitsev et al. 2014). The data matrix composed for phylogenetic analysis by Frost et al. (1991) included ten characters with different states in E. amurensis and M. dauuricus, of which six are cranial and dental characters (Table 2). The authors described special cranial features, such as the depth and shape of the suprameatal fossa (Table 2: $\# 2$ ), and important features for the separation of $M$. dauuricus - relationships between petrosal and squamosal bones for participation in the bullar roof (Table 2: \#4), and the relative height of the skull (Table 2: \#3).

Table 1. Corbet's (1988) cranial and dental characters most relevant to erinaceins classification (were extracted only Amur (EA) and Daurian (MD) hedgehogs).

\begin{tabular}{|c|l|c|c|}
\hline$\#$ & \multicolumn{1}{|c|}{ Character, with conditions } & EA & MD \\
\hline 1 & Postero-lateral angle of tympanic: (0) acute; (1) obtuse; (2) very obtuse & 0 & 2 \\
\hline 2 & $\begin{array}{l}\text { Alisphenoid, foramen for stapedial artery: (0) open behind; (1) marginally } \\
\text { enclosed; (2) completely encircled }\end{array}$ & 0 & 2 \\
\hline 3 & Maxilla-nasal contact: (0) none; (1) at point or short; (2) long & 2 & 1 \\
\hline 4 & $\begin{array}{l}\text { Maxillae, posterior process: (0) level with lacrimal foramen; (1) slightly } \\
\text { behind; (2) far behind lacrimal foramen }\end{array}$ & 1 & 2 \\
\hline 5 & I3 size: (0) small, 1 root; (1) large, 2 roots & 0 & 1 \\
\hline 6 & Upper canine roots: (0) obscurely 2-rooted; (1) clearly 2-rooted & 0 & 1 \\
\hline 7 & $\begin{array}{l}\text { P2 roots: (0) single-rooted; (1) 2-rooted, hardly separated; (2) 2-rooted, clearly } \\
\text { separated }\end{array}$ & 0 & 1 \\
\hline 8 & p4 lingual cusp: (0) none; (1) small; (2) large & 2 & 0 \\
\hline
\end{tabular}


Table 2. Morphological characters with different conditions for Amur and Daurian hedgehogs by Frost et al. (1991).

\begin{tabular}{|c|l|c|c|}
\hline$\#$ & \multicolumn{1}{|c|}{ Character, with conditions } & EA & MD \\
\hline 1 & $\begin{array}{l}\text { [\#12] Lacrimal/maxilla suture: (0) unfused and/or distinct in adults; (1) fused } \\
\text { and indistinct in young adults }\end{array}$ & 1 & 0 \\
\hline 2 & $\begin{array}{l}\text { [\#28] Squamosal, suprameatal fossa, shape: (0) "normal", anterior and } \\
\text { posterior borders widely separated; (1) "compressed", anterior and posterior } \\
\text { borders narrowly separated }\end{array}$ & 0 & 1 \\
\hline 3 & $\begin{array}{l}\text { [\#29] Parietal, relative height of skull: (0) parietals relatively higher than } \\
\text { frontals; (1) frontals relatively higher than parietals }\end{array}$ & 1 & 0 \\
\hline 4 & $\begin{array}{l}\text { [\#33] Petrosal: (0) promontorium predominantly confined to bullar roof, } \\
\text { squamosal does not participate in bullar roof; (1) promontorium forms } \\
\text { postero-medial wall, squamosal is major component of bullar roof }\end{array}$ & 0 & 1 \\
\hline 5 & $\begin{array}{l}{[\# 49] \text { I3, number of roots: (0) one root; (1) two roots, separate; (2) two roots, }} \\
\text { fused }\end{array}$ & 2 & 1 \\
\hline 6 & [\#51] C1, number of roots: (0) two roots; (1) one root or two roots fused & 1 & 0 \\
\hline
\end{tabular}

Notes: Number in square brackets corresponds to the numbers of the Frost et al. transformation series. Species acronyms see in Table 1.

Despite these works, up to the present, Amur and Daurian hedgehogs do not have clearly distinguished specific morphological characteristics. The existence of taxonomically uncertain geographic forms of $E$. amurensis and $M$. dauuricus, which are poorly defined and difficult to separate, has prevented some researchers from reviewing their intra-species variation and subspecies assignment (e.g. Hutterer, 2005); it has also led Frost et al. (1991) to include two specimens of $E$. amurensis in Mesechinus (ZMMU\#83744, 83745).

\section{Material and methods}

The studied material is presented by a set of small samples scattered among different museums. The analysed specimens comprise 99 skulls, of which 46 skulls are from Amur hedgehogs, and 53 belonged to Daurian hedgehogs (see Appendix 1). All studied materials housed in the Scientific Collections of the Institute of Zoology, Chinese Academy of Science (IOZ, Beijing, China), the Zoological Institute, Russian Academy of Sciences (ZIN, Saint Petersburg, Russia), and the Zoological Museum of Moscow State University (ZMMU, Moscow, Russia). In addition, we examined specimens (by photos) from the Natural History Museum (BM, London, United Kingdom; Scott \& Smith, 2014).

The drawings of the age stages were prepared based on high-resolution digital images using graphic program Corel Draw x5. Morphological descriptions, cranial and dental nomenclature follows MacPhee et al. (1988), Frost et al. (1991), and Gould (1995, 2001).

\section{Results}

In practice, age estimates are based on a consensus of several features (which are available for large collections). Here, relative age stages can be determined based on relative characters, such as teeth wear, skull size, and development of the sagittal ridge, nuchal crest and temporal line. Therefore, all hedgehog skulls in the study were divided into four age stages corresponding to obvious stages: (i) juvenile hedgehogs, juv; (ii) subadult hedgehogs, sad; (iii) adult animals, ad; and (iv) senile animals, sen. (see Appendix 2).

Juvenile animals. This group is characterised in both species by several morphological markers: a disproportionate short and broad rostral part of the skull; a lack of development of the sagittal crest and a fully absent nuchal crest and temporal line; all types of upper premolar teeth (dI1-dI3, i1-i2, dC, dc, dP2, dP3, dP4, dp3, dp4) being deciduous; and the upper third molar being just erupted or in the process of eruption. Available juvenile skulls of Amur and Daurian hedgehogs showed the following approximate intervals in linear measurement: condylobasal length of skull (CBL) $=40.8-41.0 \mathrm{~mm}$ in E. amurensis; and $<38.5-44.8 \mathrm{~mm}$ in $M$. dauuricus. Figure 1 illustrates the morphological differences between the deciduous and permanent third and fourth upper premolars of the Daurian hedgehog. Similar differences are found in E. amurensis. The milk dP4 tooth differs from P4 in its general size, its more posterior position of the paracone relative mesial edge of the tooth (Fig. 1,a), its relative position of the hypocone and protocone (Fig. 1,b, c), and the weakly developed notches on its distal and lingual edges (Fig. 1,d, e). Also, the crown and root part of the permanent P3 is more complicated than in $\mathrm{dP} 3$ - milk teeth are usually single-rooted. In addition, in both species we can observe similar characteristics: the lacrimal/maxilla suture (Table 2: \#1) is unfused; the level of the frontal bones is relatively lower than the parietal bones (see keys in Fig. 2A; Table 2: \#3); the anterior border of the suprameatal fossa (Table 2: \#2) is developed, and accordingly this distinctive fossa is of course present in $M$. dauuricus, but also in E. amurensis. These condi- 

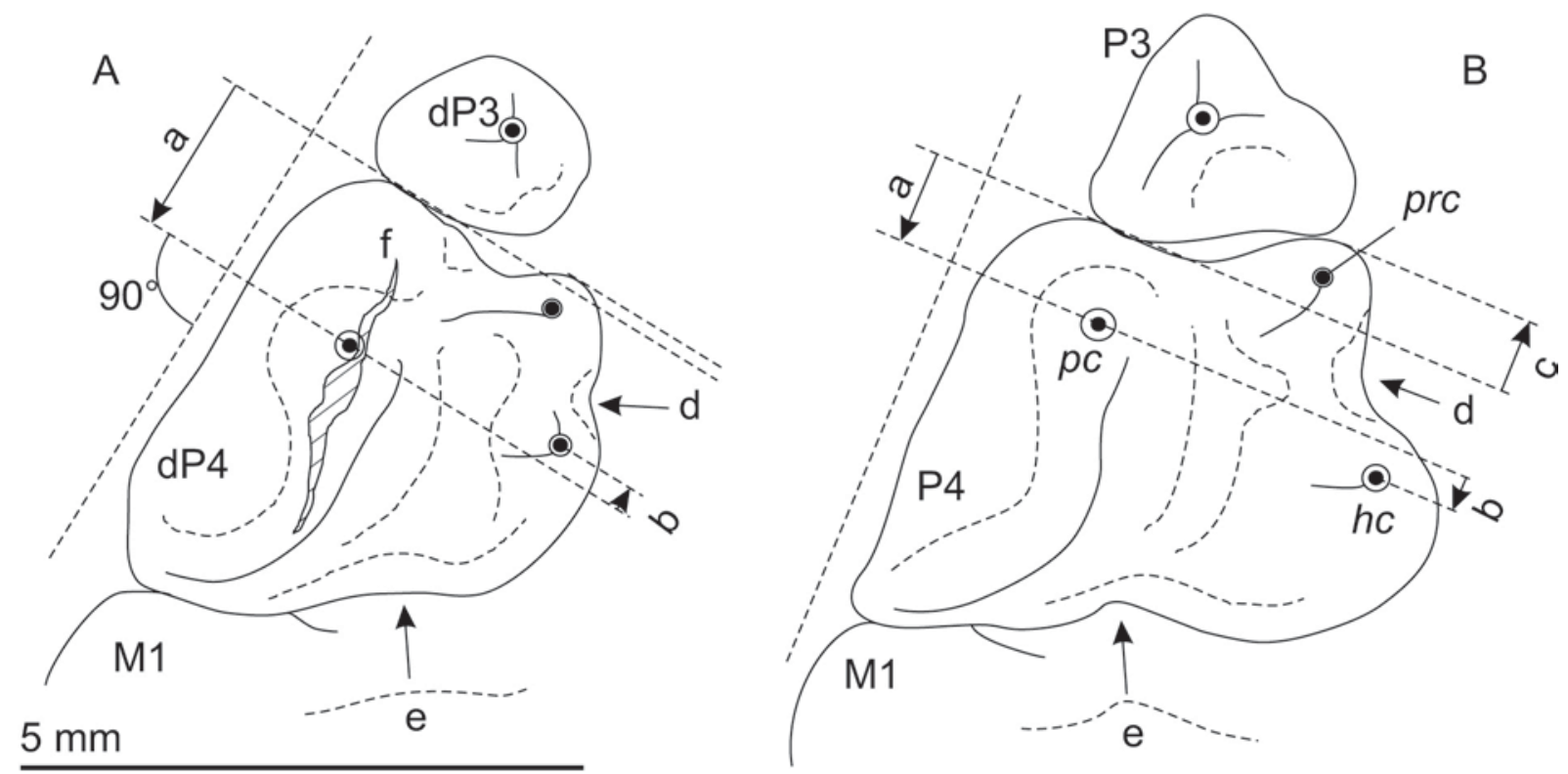

Figure 1. Diagrammatic images of occlusal view of fourth upper deciduous (A) and permanent (B) premolars of $M$. dauuricus: A - ZMMU\#42341, immature (sad) male, $C B L=49.1 \mathrm{~mm}$; B - ZMMU\#43831, mature (ad) male, $C B L=52.7 \mathrm{~mm}$.

Abbreviations: $\mathrm{a}$ - position of paraconal tip (pc) relative anterior edge of tooth; $\mathrm{b}$ - position of hipoconal tip (hc) relative pc; $\mathrm{c}$ - anterior protruding of procotoconal flange (faint for $\mathrm{dP} 4$ ); $\mathrm{d}$ - development of the lingual emargination (entocingulum); $\mathrm{e}$ - shape of the outline of posterior emargination; $\mathrm{f}$ - split along pc due to permanent tooth erupting; $\mathrm{dP} 3-\mathrm{dP} 4$ - deciduous third and fourth upper premolars; $\mathrm{M} 1$ first upper molar; P3-P4 - permanent third and fourth upper premolars; hc - hypocon; pc - paracone; prc - protocone. Scale bar = $5 \mathrm{~mm}$.

tions are connected with "juvenile compression" of new-born or young animal skulls.

Subadult animals. The interval between the lateral part of the postpalatine torus (ppt) and the posterior edge of the M3 alveolus is absent or very short (Fig. $2 \mathrm{~B} 1, \mathrm{~B} 2)$; the posterior part of the sagittal crest is developed to varying degrees; deciduous teeth, included the fourth upper and lower premolars are in the process of replacement (Fig. 2B1, C1). The general linear characteristics (CBL) in all of the studied specimens of this group are as follows: $49.3-51.6 \mathrm{~mm}$ in E. amurensis, and $49.0-50.6 \mathrm{~mm}$ in $M$. dauuricus. The sequence of the replacement of upper and lower deciduous teeth is still unclear. Examination of the available specimens showed that at least the eruption of $\mathrm{dP} 4$ followed closely after dP3. The phases of incisor, canine and anterior premolar replacement are unknown. Accordingly, Figure 3 shows that eruption of i1 and p4 in both species belong to same phase. The next stage is probably re- placement of i2, c, and p3. The level of the frontal bones (Table 2: \#3) of the Amur hedgehog rises to that of the parietal bone. However, the similarly aged Daurian hedgehogs still demonstrated juvenile characteristics in this feature. The suprameatal fossa exhibits characteristics typical for each species: the anterior border in E. amurensis is shifted antero-medialy, the fossa becomes shallow, corresponding to "anterior and posterior borders widely separated" as described by Frost et al. (1991) (Table 2: \#2). Simultaneously the borders of the fossa and its depth in $M$. dauuricus remain relatively stable with isometric size increases, following the growth of the basicranial part. Fusion of the lacrimal/ maxilla suture (Table 2: \#1) in both species is variable.

Adult animals. The interval between the lateral part of the postpalatine torus (ppt) and the posterior edge of M3 is broad (Fig. 2B3); the posterior part and part of the middle of the sagittal crest are developed; all deciduous teeth have been replaced; the main cusps of

IOZ\#03096, see A; B2 — IOZ\#04910, immature (sad) male, CBL = 51.6 mm; B3 — IOZ\#05122, mature (ad) female, CBL = $53.6 \mathrm{~mm}$; B4 - IOZ\#05120, senile (sen) female, $\mathrm{CBL}=52.02 \mathrm{~mm}$ ); $\mathrm{C} 1-\mathrm{C} 4$ - lateral view of the mandible fragments (for details see B1-B4).

Abbreviations: a - diagrammatic contour of sagittal crest with three sectors illustrating age-related changes in developing of crest; a(M3) alveolus of M3; b - diagrammatic line with horizontal arrows that shown age-related changes in size of the crown (it wear down) and bared part of root (alveolar edges resolved and subsided); C — upper canine; dP2 — deciduous second upper premolar; I1-I3 - first-third upper incisor; P2 - second upper premolar; p3 — third lower premolar; M2-M3 - second-third upper molars; mx - maxilla; pmx praemaxilla; pns — posterior nasal spine; ppt — postpalatine torus; pt — palatine; star — interval between lateral part of postpalatine torus and posterior edge of M3 alveolus illustrating age-related changes in its width; hatched polygons — teeth with vertical arrows are growing up (see B1, C1); dotted lines — worn tips of the main dental cusps of lower teeth (see C1-C4) or worn facets of upper teeth (see B3-B4); also see figs 1(a) and 2(a). Unscaled. 

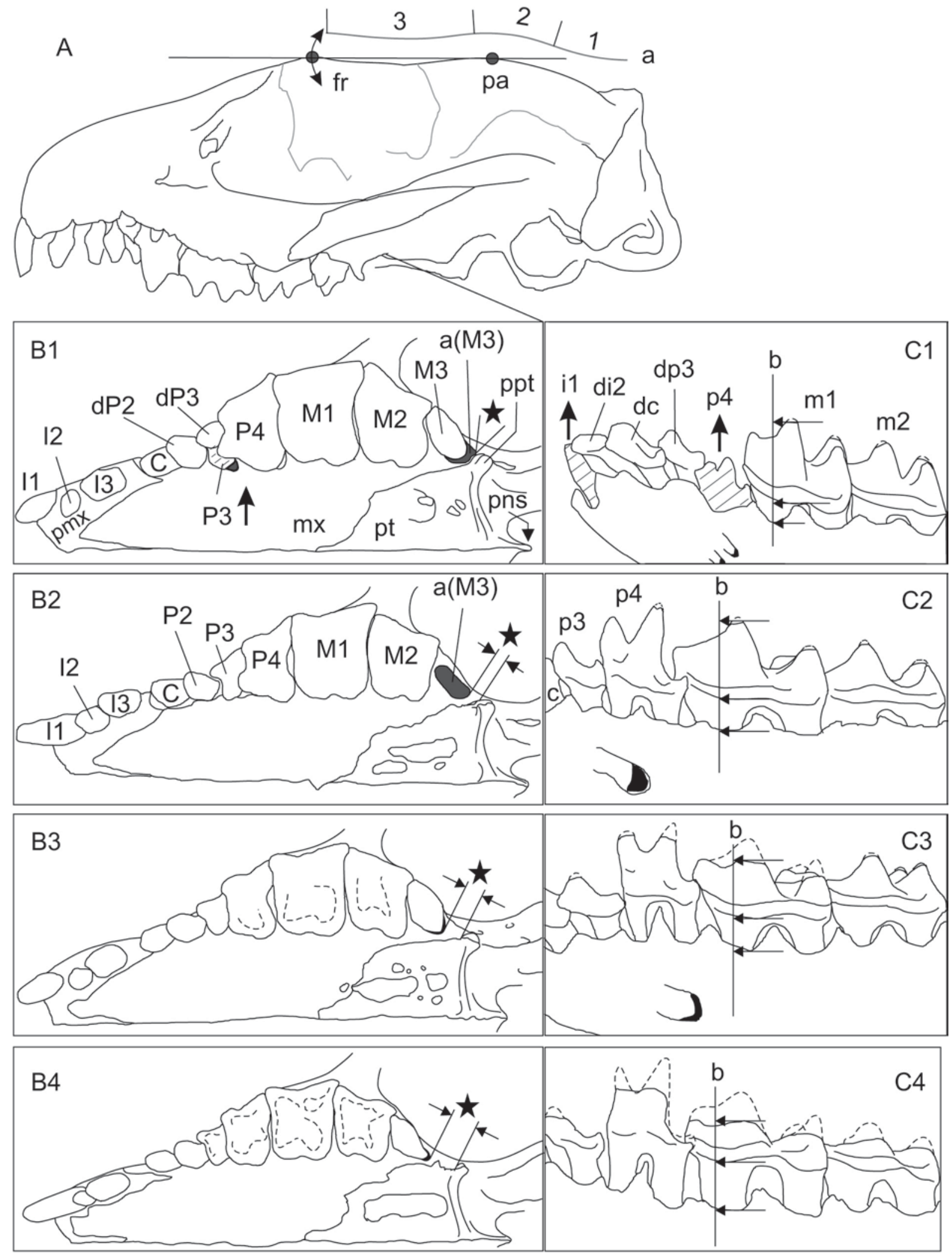

Figure 2. Diagrammatic images of skull $(\mathrm{A}, \mathrm{B} n)$ and mandible $(\mathrm{Cn})$ of $E$. amurensis illustrating age variation in the morphological structures: A - lateral view of skull with two marks that shown relative position of the frontal (fr) and parietal (pa) bones (IOZ\#03096, immature (sad) female, CBL $=49.8 \mathrm{~mm})$; B1-B4 - ventral view of rostral part of skulls (B1 - 


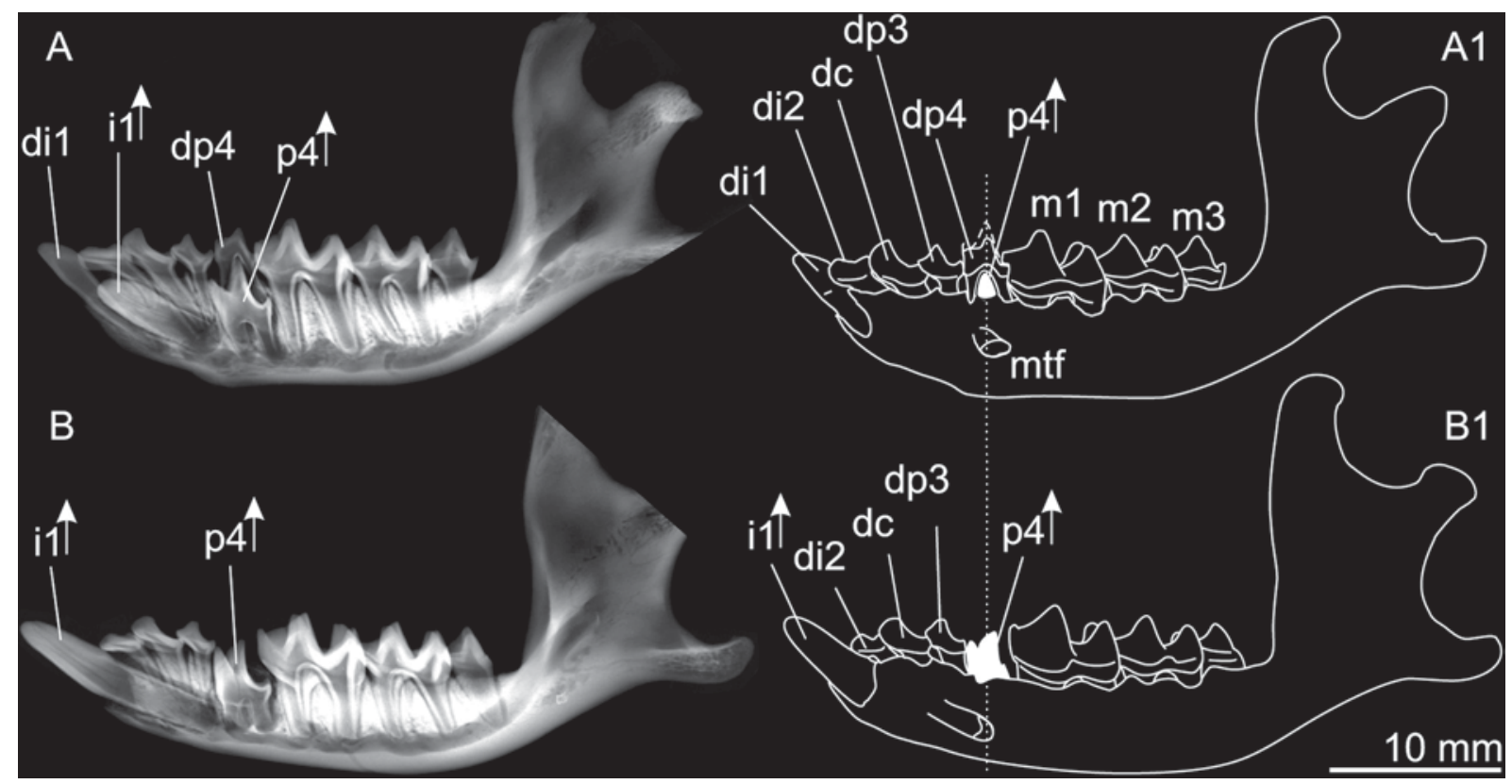

Figure 3. Radiographs (A, B) and diagrammatic images (A1, B1) of the immature (sad) hedgehogs left semi-mandible showing teeth eruption: A, A1 - E. amurensis, ZMMU\#8795, immature male, CBL $=49.2 \mathrm{~mm}$, height of mandibular coronoid process, $\mathrm{COR}=15.7 \mathrm{~mm}$; B, B1 - M. dauuricus, ZMMU\#42339, immature male, $\mathrm{CBL}=49.6 \mathrm{~mm}, \mathrm{COR}=17.8 \mathrm{~mm}$. Abbreviations: dc - deciduous lower canine; di1-di2 - deciduous first and second lower incisors; dp3-dp4 - deciduous third and fourth lower premolars; i1-i2 - first and second permanent lower incisor; $\mathrm{m} 1-\mathrm{m} 2$ - first-second lower molars; mtf — mental foremen; $\mathrm{p} 4$ fourth permanent lower premolar; vertical arrows showing the erupting teeth. Scale bar $=10 \mathrm{~mm}$.

the teeth (earlier molars) show wear (Fig. 2B3, C3). The general linear characteristics $(\mathrm{CBL})$ of this age group are as follows: $50.1-59.9 \mathrm{~mm}$ in E. amurensis, and $50.2-58.4 \mathrm{~mm}$ in $M$. dauuricus. The level of the frontal bones in the Amur hedgehog is similar to or higher than the parietal bone. The level of the frontal bones of Daurian hedgehogs rises, and can be similar to the level of the parietal bone, owing to the development of the temporal line and the slow inflation of the frontal bones (e.g. ZIN\#45234).

Senile animals. The sagittal crest is fully developed; the main cusps of the teeth are strongly worn (Fig. 2B4, C4); the lower molar teeth (Fig. 2C4) may be worn down to the level of the buccal cingulum; the alveolar edges are resolved and subsided. The CBL measurements are as follows: $52.0-55.8 \mathrm{~mm}$ in $E$. amurensis, and 55.1-58.7 $\mathrm{mm}$ in $M$. dauuricus. The relative position of the frontal and parietal bones is similar for both species.

\section{Discussion}

In accordance with the results obtained, we can determine age-related features, which may be used to describe the species differences. Those features are follows: (i) fusion of the lacrimal/maxilla suture, as used in Frost et al. (1991: TS \#12), is not strictly defined for "adult Daurian hedgehogs" and "young Amur hedgehogs" (see Table 2: \#1), because we found the several specimens with unusual characteristics in
Amur hedgehogs (subadult IOZ\#04910, adult IOZ $\# 05095,05109)$; (ii) the shape of the suprameatal fossa is connected with "juvenile compression" of the basal part of the skull, and demonstrated similar characteristics in new-born and juvenile specimens of both species; furthermore, in Mesechinus the fossa continues to develop and becomes deeper towards the anterior border; conversely, the fossa of Erinaceus turns outward and becomes shallow, with simultaneous disappearance of the anterior border. However, in several cases E. amurensis exhibited the remains of a small part of the anterior border of the fossa (Fig. 4D); (iii) the relative height of skull changed in both species, but this process is not contemporaneous - the specific skull profile with pronounced temporal lines in E. amurensis is acquired earlier than in M. dauuricus - but adult and senile specimens of both species demonstrated similar lateral skull profiles (more precisely, adult and senile males of Daurian hedgehogs).

Other features, that are mentioned in tables 1 and 2 are usually not used for species identification, in part because some of them demonstrate wide variations (e.g. root number and size of the tooth crowns; maxilla/ nasal suture; conditions of the foramen of the stapedial artery in Table 1), and partly because some of them are very difficult to measure (e.g. petrosal conditions in Table 2; angle of the tympanic bone in Table 1). These named features were not included in the identification keys of Corbet (1988: 138) or Frost et al. (1991: 22), because in these authors' opinion the two sympatric 


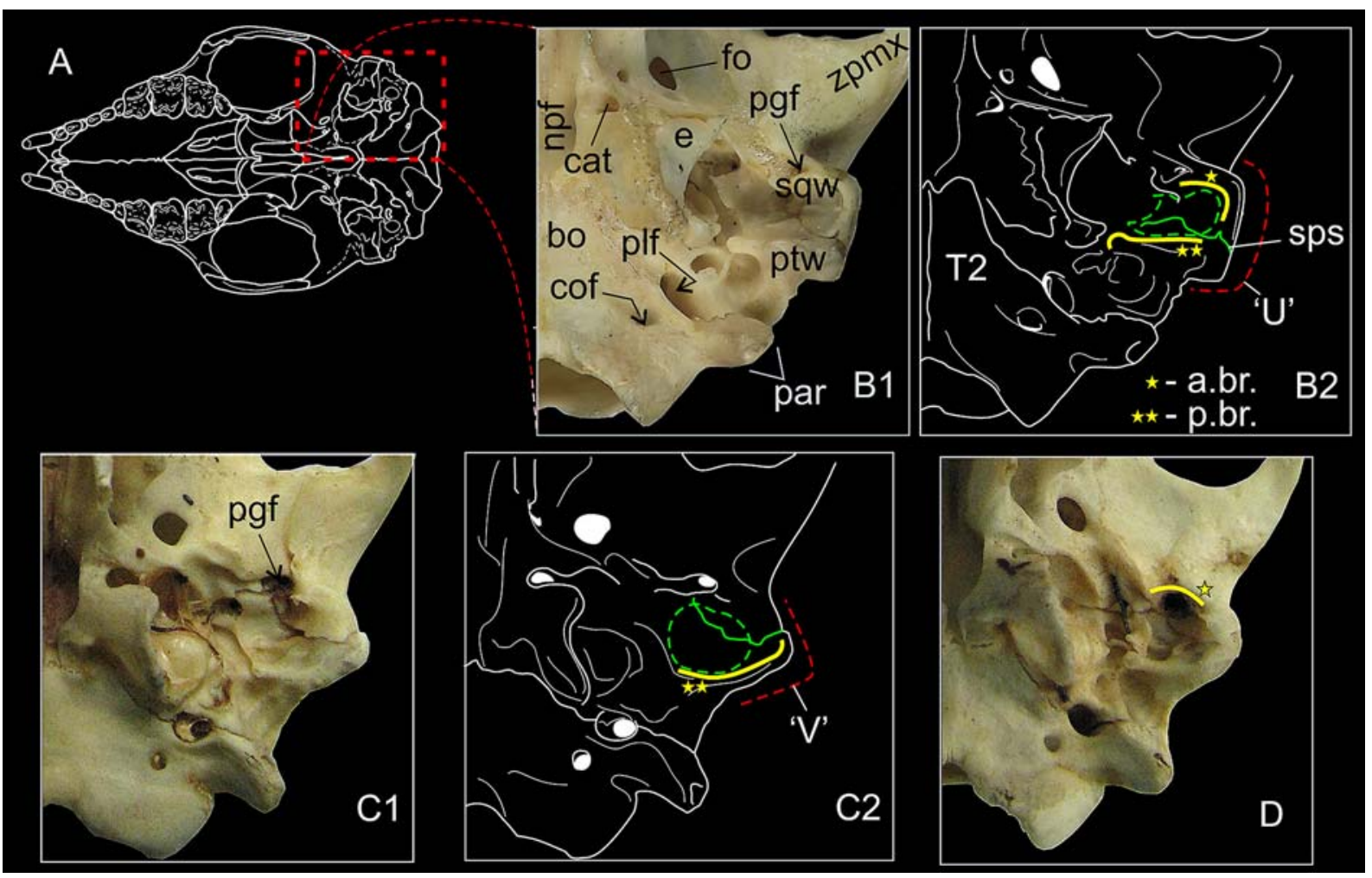

Figure 4 The photos and images of basicranium of the hedgehogs with highlights of temporal bone structures: A diagrammatic image illustrating the position of studying structures on ventral side of a skull; B1 — photo of left part of basicranium of $M$. dauuricus (ZIN\#45234); B2 - diagrammatic image of photo B1; C1, C2 — photo and image of $E$. amurensis (IOZ\#04910); D - photo of immature E. amurensis (IOZ\#03096) with slightly developed anterior border of suprameatal fossa (sup).

Abbreviations: a.br. — anterior border of sup; bo — basioccipitale; cat — channel for auditory tube; e — ectotympanic; fo — foramen ovale; npf — nasopharynx fossa; par — paroccipital process; pgf — postglenoid foramen; plf — posterior lacerate foramen; p.br. posterior border of sup; ptw — mastoid process (or rather petrosal wing of sup); sqw — squamosal epitympanic wing; sps — squamopetrosal suture; 'U' - U-shaped contour of sup; 'V' - V-shaped contour of sup; zpmx — zygomatic process of maxilla; green dotted line is approximate outline of sup; green solid line is sps. Unscaled.

species (sympatric territories are known in the steppe and wood-steppe habitats of North-East China, east of the Great Khingan Ridge) belong to different genera, and there is no need to compare them directly.

\section{Conclusion}

From our own practice working with museum collections of hedgehogs from eastern China, we know that there is a high probability that juvenile Amur or Daurian hedgehogs cannot be immediately identified. The size and additive characteristics of the suprameatal fossa are undoubtedly very useful for the identification of adult specimens of both species, but they are useless for young specimens due to similarity of the initial stages of ear-region development. The same applies to the relative height of the frontal and parietal bones development of the sagittal ridge and the temporal line cannot be used for correct comparison of subadult and adult $E$. amurensis with adult and senile males of $M$. dauuricus, because the skull profiles of the species become similar with maturity of $M$. dauuricus.
Thus, all of the characteristics that are generally used for the comparison and identification of EastAsian hedgehogs, in particular E. amurensis and $M$. dauuricus, require a prior description of the interspecific variability in order to be useful for species identification.

ACKNOWLEDGEMENTS. We wish to thank to the Dr. Deyan Ge from the Key Laboratory of Zoological Systematics and Evolution, Institute of Zoology, Chinese Academy of Sciences and the National Zoological Museum of China (Beijing) to provide access to Chinese Collection specimens. Our grateful to staff of Zoological Museum of the Moscow State University, mainly Andrey Lissovsky, Ekaterina Obolenskaya, Sergei Kruskop, and Vladimir Lebedev, for their support of our work with collections. Our grateful to Ekaterina Petrova and Mikhail Nazarkin (x-ray images) for technical support of this work. Our thanks to staff of NHM Images (Picture Library), namely Dr. Isabel Martin and Dr. Revinder Chahal for providing us images of type specimens. This study was fulfilled within the frame- 
work of the Federal themes of the Theriology Laboratory of ZIN RAS no. AAAA-A17-117022810195-3 "Phylogeny, morphology and systematics of placental mammals"; it was supported by the Federal Agency for Scientific Organizations program for the support to bioresource collections; and it was partly financially supported by the Russian Foundation for Basic Research, project no. 16-04-00294 A.

\section{References}

Corbet G.B. 1988. The family Erinaceidae; a synthesis of its taxonomy, phylogeny, ecology and zoogeography // Mammal Review. Vol.18. P.117-172.

Frost D.R., Wozencraft W.C. \& Hoffmann R.S. 1991. Phylogenetic relationships of hedgehogs and gymnures (Mammalia: Insectivora; Erinaceidae) // Smithsonian Contributions to Zoology. Vol.518. P.1-69.

Gould G.C. 1995. Hedgehog phylogeny (Mammalia, Erinaceidae) - the reciprocal illumination of the quick and the dead // American Museum Novitates. No.3131. P.1-45.

Gould G.C. 2001. The phylogenetic resolving power of discrete dental morphology among extant hedgehogs and the implications for their fossil record // American Museum Novitates. No.3340. P.1-52.

Hutterer R. 2005. Order Erinaceomorpha // Wilson D.E. \& Reeder D.M. (eds.). Mammal Species of the World. Baltimore: Johns Hopkins University Press. Vol.1. P.212219.

Klevesal G.A. 2007. [Principles and Methods of Age Determination of Mammals]. Moscow: KMK Scientific Press. 283 p. [In Russian]
MacPhee R.D.E., Novacek M.J. \& Storch G. 1988. Basicranial morphology of Early Tertiary erinaceomorps and the origin of primates // American Museum Novitates. No.2921. P.1-42.

Matschie P. 1908. Über chinesische Säugetiere, besonders aus den Sammlungen des Herrn Wilhelm Filchner // Filchner W. (Hrsg.). Wissenschaftliche Ergebnisse der Expedition Filchner nach China und Tibet (1903-1905): Zoologische Sammlungen. Botanische Sammlungen. Berlin: Ernst Siegfried Mittler und Sohn. Bd.10. S.134244.

Mori T. 1922. On two forms of the Korean hedgehog // The Annals and Magazine of Natural History. Ser.9. Vol.10. P.614-616.

Morris P.A. 1970. A method for determining absolute age in the hedgehog // Jounal of Zoology. Vol.161. P.277-281.

Morris P.A. 1971. Epiphyseal fusion in the forefoot as a means of age determination in the hedgehog (Erinaceus europaeus) // Notes from the Mammal Society. Vol.22. P.254-259.

Reeve N. 1994. Hedgehogs. London: T \& AD Poyser (Natural History). 313 p.

Scott B. \& Smith V. 2014. Dataset title data.nhm.uk http:// dx.doi.org/10.5072/1 (accessed 20 September 2017)

Thomas O. 1908. The Duke of Bedford's zoological explorations in Eastern Asia, XI: On mammals from the province of Shan-si and Shen-si, Northern China // Proceedings of the Zoological Society of London. Vol.3. P.963983.

Zaitsev M.V., Voyta L.L. \& Sheftel B.I. 2014. [The Mammals of Russia and Adjacent Territories: Lipotyphlans]. St. Petersburg: Izdatel'stvo Nauka. Vol.178. 391 p. [In Russian]

Appendix 1. The total list of examined specimens used in describing of relative age stages of E. amurensis and $M$. dauuricus. Information is in the following order: species name, museum acronyms, specimen ID numbers/second number (if present), locality in parentheses, and size of a sample in square brackets. Bolded ID numbers correspond to type specimens. Institutional abbreviations see in Material section.

Erinaceus amurensis Schrenk, 1858

BM\#1922.10.6.1 (Korea: Chosen), 1861.6.2.5 (China: Shun-I-Hsien) $[n=2]$;

IOZ: 01220 (China: Huaide), 03096/32190 (China: Beijing), 04867 (China: W of Beijing), 04909/31826 (China: Beijing), 04910 (China: W of Beijing), 05095 (China: W of Beijing), 05103/60666 (China: Hebei, Guan), 05109 (China: Beijing), 05119 (China: Shandong, East of Jinan), 05120-125 (China: Shandong), 09341 (China: Yichun), 12741 (China: Jilin), 13305 (China; Heilongjiang), 13429-432 (China: Beijing), 15854 (China: Henan, Kaifeng), 15856 (China: Jilin), 30988-989 (China: Beijing), 32014 (China: Tianjin), 32015/0001 (China: Shanghai), 32016/0002 (China: Shanghai), 32017/0003 (China: Zhejiang), 32019/354 (China: Shanghai), 32020/ 355 (China: Shanghai), 32021/356 (China: Shanghai), 63201 (China: Yichun), 74863 (China: Jilin) $[n=35]$;

ZIN: 1857 (Russia: Primorie), 7485 (Russia: Primorie), 7557 (China: Inner Mongolia), 38619 (China: Heilongjiang), 42277 (Russia: Primorie) $[n=5]$;

ZMMU: 14308 (Russia: Primorie), 14313 (Russia: Primorie), 83741 (China: Inner Mongolia), 83742 (China: Heilongjiang), 173215 (Russia: Primorie), 176464 (Russia: Primorie) [ $n=6]$.

Mesechinus dauuricus (Sundevall, 1842)

BM\#1909.1.1.9 (China: Yulin-fu) $[n=1]$;

IOZ: 10665-668 (China: Xilinguole), 01824/30650 (China: Fuxin), 01825 (China: Fuxin), 01827/31081 (China: Fuxin), 02050 (China: Kaitong), 13437 (China: Beijing), 15855 (China: Hailaer), 20565 (China: Ewenkeqi), 20842 (China: Inner Mongolia), 21295 (China: Inner Mongolia), 24276-277 (China: Xilinguole), 53005 (China: Xilinguole), 62050 (China: Kaitong) $[n=17]$; 
ZIN: 2022 (Northern China), 7564-7568 (Russia: Zabaikalskii Kray), 35758-759 (Russia: Buryatia), 85644647 (Russia: Buryatia) $[n=11]$;

ZMMU: 3294 (Russia: Buryatia), 42339 (Russia: Zabaikalskii Kray), 42341 (Russia: Zabaikalskii Kray), 43830 (Russia: Zabaikalskii Kray), 45321 (Russia: Zabaikalskii Kray), 49170 (Russia: Zabaikalskii Kray), 51105 (Mongolia: Dornod Aimag), 83732 (Russia: Zabaikalskii Kray), 83733 (Russia: Zabaikalskii Kray), 83736 (Russia: Zabaikalskii Kray), 83739 (China: Qiqihar), 83740 (China: Inner Mongolia), 83750 (Russia: Zabaikalskii Kray), 100709 (Russia: Zabaikalskii Kray), 128150 (Mongolia: Khentii Aimag), 137947 (Mongolia: South-East of Dornod Aimag), 141907 (Russia: Zabaikalskii Kray), 176486 (Russia: Buryatia), 179190 (Mongolia: Bulgan), 186307 (Mongolia: Ulaanbaatar Municipality), 187102 (Mongolia: Övörkhangai), 187445 (Mongolia: Bulgan), 191006 (Mongolia: Bulgan), 191008 (Mongolia: Bulgan), 194065 (Mongolia: Sukhbaatar) $[n=25]$.

Appendix 2. The list of examined specimens of E. amurensis and M. dauuricus sorted by relative age stages. Information is in the following order: age stage (bolded), species name, museum acronyms, specimen ID numbers, sex in parentheses, size of a sample in square brackets. Abbreviations: $\mathrm{m}$ - male; $\mathrm{f}$ - female; see also Appendix 1.

Juvenile group

Erinaceus amurensis Schrenk, 1858

ZMMU\#14308 (f), 14331 (f), 14332 (m) [ $n=3]$.

Mesechinus dauuricus (Sundevall, 1842)

IOZ\#01824, $10668(\mathrm{~m})[n=2]$.

Subadultus group

Erinaceus amurensis Schrenk, 1858

BM\#1922.10.6.1, 1861.6.2.5 $[n=2]$;

IOZ\#03096 (f), 04910 (m), 12741 (f) [ $n=3]$;

ZMMU\#8795 (m), 14329 (f), 14334 (m), 176465 (f), 83742 (m) [n=4].

Mesechinus dauuricus (Sundevall, 1842)

IOZ\#13437, \#31081 (f) [ $n=2]$;

ZMMU\#42340, 43831 (m), 42832 (f) $[n=3]$;

ZIN\#42339 [ $n=1]$.

Adultus group

Erinaceus amurensis Schrenk, 1858

IOZ\#04909 (f), 05095 (f), 05109, 05122 (f), 05123 (f), 09341 (m), 15854 (m), 15856 (f) [ $n=8]$;

ZMMU\#14313 (f), 14315 (f), 83741 (f), 89357, 173215 (m), 176466 (m) [n=6];

ZIN\#1857 (m), 7485 (f), 7557, $18401[n=4]$.

Mesechinus dauuricus (Sundevall, 1842)

BM\#1909.1.1.9 $[n=1]$;

IOZ\#20565 (f), 20842 (m), 21293 (f), 24276 (f), 24277 (m) [n= 5];

ZMMU\#3294, 43831 (m), 43833, 51105 (m), 83733 (f), 83736 (m), 83747 (f), 100455 (f), 100456 (m), 107219 (f), 113799, 176486 (m), 186307 (m) [ $n=13]$.

ZIN\#2022 (f), $45234[n=2]$.

Senile group

Erinaceus amurensis Schrenk, 1858

IOZ\#05120 (f), 05121 (m), 05124 (f), 05125 (m) $[n=4]$;

ZMMU\#83745 (m) $[n=1]$.

Mesechinus dauuricus (Sundevall, 1842)

IOZ\#15855 (f) $[n=1]$;

ZMMU\#45321 (f), 83737 (m), 176487 (m), 194065 (f) [n=4]. 